\title{
Factorial Analysis on Flooded Soil Recovery Using Soil Containing Arbuscular Mycorrhizal Fungi
}

\author{
N. Zainol ${ }^{1, *}, N$. Thangaperumal, N.H. Zahari and N.H. Aziz \\ ${ }^{1}$ Faculty of Chemical \& Natural Resources Engineering, Universiti Malaysia Pahang, 26300 Gambang, \\ Pahang, MALAYSIA.
}

\begin{abstract}
This paper presents the factorial analysis on flooded soil (FS) recovery using soil containing Arbuscular Mycorrhizal fungi (SA) with the help of a selected host plant, Allium cepa L. (onion plant). In order to study the most contributing factor for the soil recovery, five factors were selected namely; $\mathrm{pH}$ of soil, water content, SA/FS ratio, light supply and depth of soil. This was to study the ability of SA to recover the nutrients (nitrogen, phosphorus and potassium) in the FS. Experimental design table was constructed using the concept of two levels factorial by employing DesignExpert ${ }^{\circledR}$ software (Ver 7.1.6). Soil sample was collected after 12 days and analyzed for nitrogen, phosphorus and potassium concentrations using $\mathrm{HACH}$ Spectrophotometer. Later, the data was analyzed in the named software to determine the main effect of respective factors and interaction between factors. The results showed that water content, light supply and depth of soil were the important factors for nutrients recovery. The best condition for FS recovery using SA was at: $\mathrm{pH}$ of the soil (4), water content $(28 \mathrm{ml}), \mathrm{SA} / \mathrm{FS}$ ratio (1:5), depth of soil $(5 \mathrm{~cm})$ and with light supply.
\end{abstract}

\section{Introduction}

Rainy seasons in the eastern part of Peninsular Malaysia which occurs in the period between October and March always bring about the devastating effect not only to the people but also to the ecosystem. This effects on may aspects of industries, especially on agricultural soil since agriculture, occupies a large proportion of the landscape. Flooded soils create significant challenges for agricultural lands. The floods have many direct impacts, with the most prominent one being the flooded soil syndrome where the soils losses their beneficial fungi which mobilize soil-based plant nutrients. Flooding and long periods of waterlogging have resulted in the depletion of nutrients. Prolonged flooding reduces the concentration of nitrogen $(\mathrm{N})$, phosphorus, $(\mathrm{P})$ and potassium, $(\mathrm{K})$. $\mathrm{N}$ appears

\footnotetext{
*Corresponding author: azwinaz@gmail.com
} 
to have been denitrified and lost from the system. Since P uptake depends on microbes in most plant, prolonged waterlogging has reduced microbial activity which in turn affects the absorption of $\mathrm{P}$ into the plant roots [1]. Soil $\mathrm{K}$ is less available in the soils that remain wet since wet soils are more prone to compaction, which restricts plant root growth and uptake of soil K.

Arbuscular Mycorrhizal fungi (AMF) is a soil borne fungi found in almost any habitat worldwide. Symbiotic associations between AMF and plant roots are widespread in the natural environment and can provide a range of benefits to the host plant. These include improved nutrition, enhanced resistance to soil-borne pests and disease, improved resistance to drought, tolerance of heavy metals and better soil structure [2]. AMF enlarges the soil volume from which nutrients can be taken up, via an extensive mycelium network, enabling host plants to access more resources. As a consequence, AMF enhances uptake of nutrients, particularly phosphorus [3], and may allow for a reduction of the amount of fertilizers applied [4]. Hence, this study attempts to manipulate the ability of AMF in facilitating nutrient uptake to recover the infertile flooded soil with the help of onion plant as a host.

\section{Materials and Methods}

\subsection{Experimental set-up}

The onion plant (Allium cepa L.) was selected as a host plant in this study. The soil containing AMF (SA) was collected from the domestic vegetable garden and kept in the ambient temperature. Then, simulated flooded soil (FS) was prepared by submerging the agriculture soil in the water for two weeks. The mixed soil was prepared by mixing the SA and FS according to the experimental design table (Table 1). Onion bulb was planted in the mixed soil for twelve days and planted in ambient temperature. There were 16 pots that represented 16 runs in experimental design table.

Table 1. Experimental design table for two levels factorial analysis.

\begin{tabular}{cccccc}
\hline Run & $\begin{array}{c}\text { Factor A: } \\
\text { pH of soil }\end{array}$ & $\begin{array}{c}\text { Factor B: } \\
\text { Water content }\end{array}$ & $\begin{array}{c}\text { Factor C: } \\
\text { SAA/FS ratio }\end{array}$ & $\begin{array}{c}\text { Factor D: } \\
\text { Light supply }\end{array}$ & $\begin{array}{c}\text { Factor E: } \\
\text { Depth of soil } \\
{[\mathbf{c m}]}\end{array}$ \\
\hline 1 & 8 & 36 & $1: 5$ & Absent & 3 \\
2 & 4 & 36 & $1: 5$ & Absent & 5 \\
3 & 4 & 28 & $1: 5$ & Present & 5 \\
4 & 8 & 36 & $1: 1$ & Absent & 5 \\
5 & 4 & 36 & $1: 1$ & Absent & 3 \\
6 & 8 & 28 & $1: 5$ & Present & 3 \\
7 & 4 & 36 & $1: 1$ & Present & 3 \\
8 & 8 & 28 & $1: 1$ & Absent & 5 \\
9 & 8 & 36 & $1: 5$ & Present & 5 \\
10 & 4 & 28 & $1: 1$ & Absent & 5 \\
11 & 4 & 28 & $1: 1$ & Present & 3 \\
12 & 8 & 36 & $1: 1$ & Present & 3 \\
13 & 8 & 28 & $1: 1$ & Present & 5 \\
14 & 4 & 36 & $1: 5$ & Present & 3 \\
15 & 8 & 28 & $1: 5$ & Absent & 5 \\
16 & 4 & 28 & $1: 5$ & Absent & 3 \\
\hline
\end{tabular}




\subsection{Sample Analysis}

Soil sample near the onion plant roots was analysed for the N, P, K concentrations by using HACH Spectrophotometer. In order to test potassium content, Potassium 1, 2, 3 reagent powder pillows were used as a reagent by using tetraphenylborate method (Method 8049). Potassium in the sample reacts with sodium tetraphenylborate to form an insoluble white solid. The amount of turbidity produced was proportional to the potassium concentration. Nitrogen was analysed using persulfate digestion method (Method 10071). An alkaline persulfate digestion converts all form of nitrogen to nitrate. Sodium metabisulfite was added after the digestion to eliminate halogen oxide interferences. Nitrate then reacted with chromotropic acid under strongly acidic conditions to form a yellow complex. The measurement wavelength was $420 \mathrm{~nm}$ for the spectrophotometer. For the phosphorus concentration, the potassium persulfate powder pillow was used with sodium hydroxide as a standard solution (Method 10127). Phosphate that present in organic and condensed inorganic forms must be converted to reactive orthophosphate before analysis. Organic phosphates were converted to orthophosphate by heating with acid and persulfate. Orthophospate reacted with molybdate in an acid medium to produce a phosphomolybdate complex. In the presence of vanadium, yellow vanadomolybdophosphoric acid forms. The intensity of the yellow colour was proportional to the phosphate concentration.

\subsection{Statistical Analysis}

Analysis of variance (ANOVA) was performed by using the Design-Expert ${ }^{\circledR}$ software (Ver 7.1.6). Data for the analysis were concentrations of Nitrogen (N), Phosphorous (P) and Potassium (K) in the soil from HACH Spectrophotometer.

\section{Results and Discussion}

\subsection{Nitrogen}

Data from the analysis showed that $\mathrm{N}$ concentration ranged from 1.1667 to $11.9333 \mathrm{mg} / \mathrm{L}$. $\mathrm{N}$ is a limiting nutrient in many terrestrial ecosystems [5]. AMF can transfer inorganic $\mathrm{N}$ (NO3- or NH4+) to their host plant [6] as it can pull up the nutrients from deep down the soil for the host plant. These ions can readily move to the root via diffusion with the presence of water. Plants that form the AMF symbiosis frequently occur in ecosystems with high nitrification rates [7]. However, $\mathrm{N}$ limitation can occur even in these ecosystems [8] and nitrate acquisition via AMF might offer an advantage to the host plant in highly competitive environments, as in the analogous case of root proliferation in patches of organic material [9]. From Pareto Chart in Figure 1 it shows that the interaction between factor $\mathrm{C}$ (SA/FS ratio) and factor D (light supply) was the highest, meaning interaction between $\mathrm{CD}$ gave the most contribution to $\mathrm{N}$ recovery in FS with $35.22 \%$. This was followed by only factor D with $23.07 \%$. It clearly indicates that light supply plays a very important role for the host plant to pull up $\mathrm{N}$.

Table 2 shows the ANOVA for N recovery in FS. The p-value of main effects (CD) is smaller than 0.0001 implies the significance of the interaction factors. The 2-way interactions give R2 $=0.9955$ show their significance at $99.55 \%$ confidence level. 


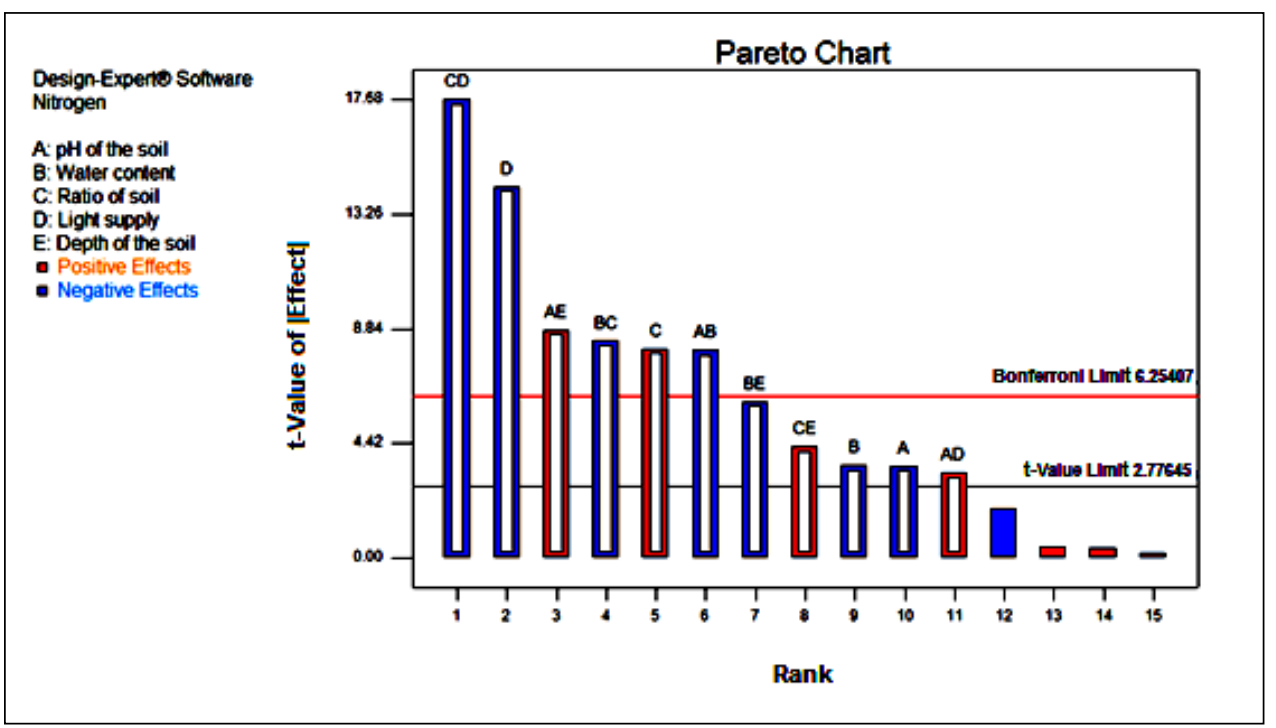

Fig. 1. Pareto chart for nitrogen.

Table 2. ANOVA table for nitrogen.

\begin{tabular}{|l|c|c|c|c|c|}
\hline Source of variation & $\begin{array}{c}\text { Sum of } \\
\text { squares }\end{array}$ & $\begin{array}{c}\text { Degree of } \\
\text { freedom }\end{array}$ & $\begin{array}{c}\text { Mean } \\
\text { square }\end{array}$ & F value & $\begin{array}{c}\text { p value } \\
\text { Prob }>\text { F }\end{array}$ \\
\hline Model & 138.17 & 11 & 12.56 & 80.29 & 0.0004 \\
\hline A, pH of soil & 1.94 & 1 & 1.94 & 12.38 & 0.0245 \\
\hline B, Water content & 1.98 & 1 & 1.98 & 12.68 & 0.0236 \\
\hline C, Soil ratio & 10.19 & 1 & 10.19 & 65.11 & 0.0013 \\
\hline D, Light supply & 32.02 & 1 & 32.02 & 204.64 & 0.0001 \\
\hline $\mathrm{AB}$ & 9.98 & 1 & 9.98 & 63.76 & 0.0013 \\
\hline $\mathrm{AD}$ & 1.67 & 1 & 1.67 & 10.66 & 0.0309 \\
\hline $\mathrm{AE}$ & 12.08 & 1 & 12.08 & 77.18 & 0.0009 \\
\hline $\mathrm{BC}$ & 10.94 & 1 & 10.94 & 69.96 & 0.0011 \\
\hline $\mathrm{BE}$ & 5.64 & 1 & 5.64 & 36.05 & 0.0039 \\
\hline $\mathrm{CD}$ & 48.88 & 1 & 48.88 & 312.45 & $<0.0001$ \\
\hline $\mathrm{CE}$ & 2.86 & 1 & 2.86 & 18.29 & 0.0129 \\
\hline Residual & 0.63 & 4 & 0.16 & & \\
\hline Correlation Total & 138.8 & 15 & & & \\
$\mathrm{R}^{2}$ & 0.9955 & & & & \\
Adj. $\mathrm{R}^{2}$ & 0.9784 & & & & \\
\hline
\end{tabular}

\subsection{Phosphorus}

The result shows that $\mathrm{P}$ concentration was between the ranges of 17.23 to $26.03 \mathrm{mg} / \mathrm{l}$. According to Shukla et al [10], both AMF and their host plants need P, and work hard to accumulate $\mathrm{P}$. One of the main functions of AMF is to extract $\mathrm{P}$ from the soil. But when soluble $\mathrm{P}$ is abundant, the host plants tend to increase their restrictions to AMF, resulting in lower levels of root colonisation. Therefore, under conditions of high available $\mathrm{P}$, the restrictions are increased. This has been proved by Shukla et al [10] who studied different $P$ levels on AMF colonisation on different plants. For phosphorus recovery, the interaction of factor B (water content) and E (depth of soil) was the highest at $18.63 \%$ contribution 
(Fig. 2). Both of these factors were associated with the soil condition. Factor D (light supply) and interaction between factor $\mathrm{A}(\mathrm{pH}$ of soil) and $\mathrm{B}$ were at the same contribution around $16 \%$. As they were all positive effects, the $\mathrm{P}$ recovery increased with the contribution of respective factors.

Table 3 summarizes the ANOVA (F-test) and p-value for P recovery in FS. It was observed from the ANOVA analysis that the confidence level was greater than $95 \%$ while the p-value of the model was 0.0009. The model with the p-value below 0.05 was statistically significant, which implied that the model was suitable for this experiment. The p-value of main effects (BE) is 0.0008 implies the significance of the interaction factors.

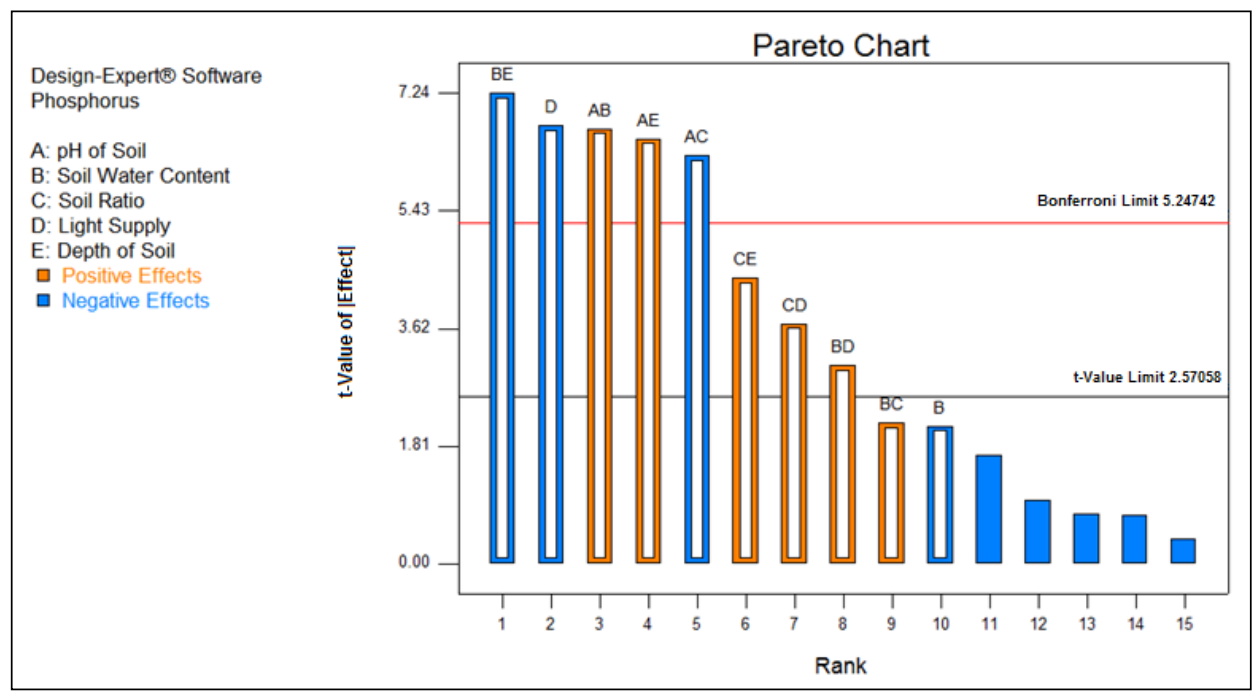

Fig. 2. Pareto chart for phosphorus.

Table 3. ANOVA table for phosphorus.

\begin{tabular}{|l|l|l|l|l|l|}
\hline Source of variation & $\begin{array}{l}\text { Sum of } \\
\text { squares }\end{array}$ & $\begin{array}{l}\text { Degree of } \\
\text { freedom }\end{array}$ & $\begin{array}{l}\text { Mean } \\
\text { square }\end{array}$ & F value & $\begin{array}{l}\text { p value } \\
\text { Prob>F }\end{array}$ \\
\hline Model & 114.40 & 10 & 11.40 & 27.61 & 0.0009 \\
\hline B, Water content & 1.85 & 1 & 1.85 & 4.45 & 0.0886 \\
\hline D, Light supply & 18.85 & 1 & 18.85 & 45.49 & 0.0011 \\
\hline AB & 18.56 & 1 & 18.56 & 44.79 & 0.0011 \\
\hline AC & 16.34 & 1 & 16.34 & 39.42 & 0.0015 \\
\hline AE & 17.11 & 1 & 17.11 & 42.74 & 0.0013 \\
\hline BC & 1.94 & 1 & 1.94 & 4.67 & 0.0830 \\
\hline BD & 3.84 & 1 & 3.84 & 9.26 & 0.0287 \\
\hline BE & 21.70 & 1 & 21.70 & 52.37 & 0.0008 \\
\hline CD & 5.64 & 1 & 5.64 & 13.61 & 0.0142 \\
\hline CE & 7.98 & 1 & 7.98 & 19.26 & 0.0071 \\
\hline Residual & 2.07 & 5 & 0.41 & & \\
\hline $\begin{array}{l}\text { Correlation Total } \\
\text { R }\end{array}$ & 116.47 & 15 & & & \\
Adj. R $^{2}$ & 0.9822 & & & & \\
\hline
\end{tabular}




\subsection{Potassium}

The result shows that $\mathrm{K}$ concentration was between the ranges of 3.5 to $8.7 \mathrm{mg} / \mathrm{L}$. As per study, potassium is one of the most important macronutrients for all organisms, especially plants. Maintaining the elevated K concentration in plants cells is vital for the smooth running of such physiological processes $[11,12]$. Potassium ions are abundant in soil; however, the availability is very low due to their strong mineral adsorption. According to this research, initially the simulated flooded soil did not contain any nutrients (N, P and K). $\mathrm{AMF}$ was the intermediate to absorb $\mathrm{K}$ from the soil, indirectly helped to gain the $\mathrm{K}$ in the soil. The depth of the soil and water content were the most important factors in $\mathrm{K}$ recovery (Fig. 3). K concentration decreased as both of these factors increased.

Table 4 shows the ANOVA analysis for K recovery in FS. It was observed from the ANOVA analysis that the confidence level was $99.92 \%$ while the p-value of the model was less than 0.0001 . The model with the p-value below 0.05 was statistically significant, which implied that the model was suitable for this experiment. The p-value of main effects (CD) is less than 0.0001 implies the significance of the interaction factors.

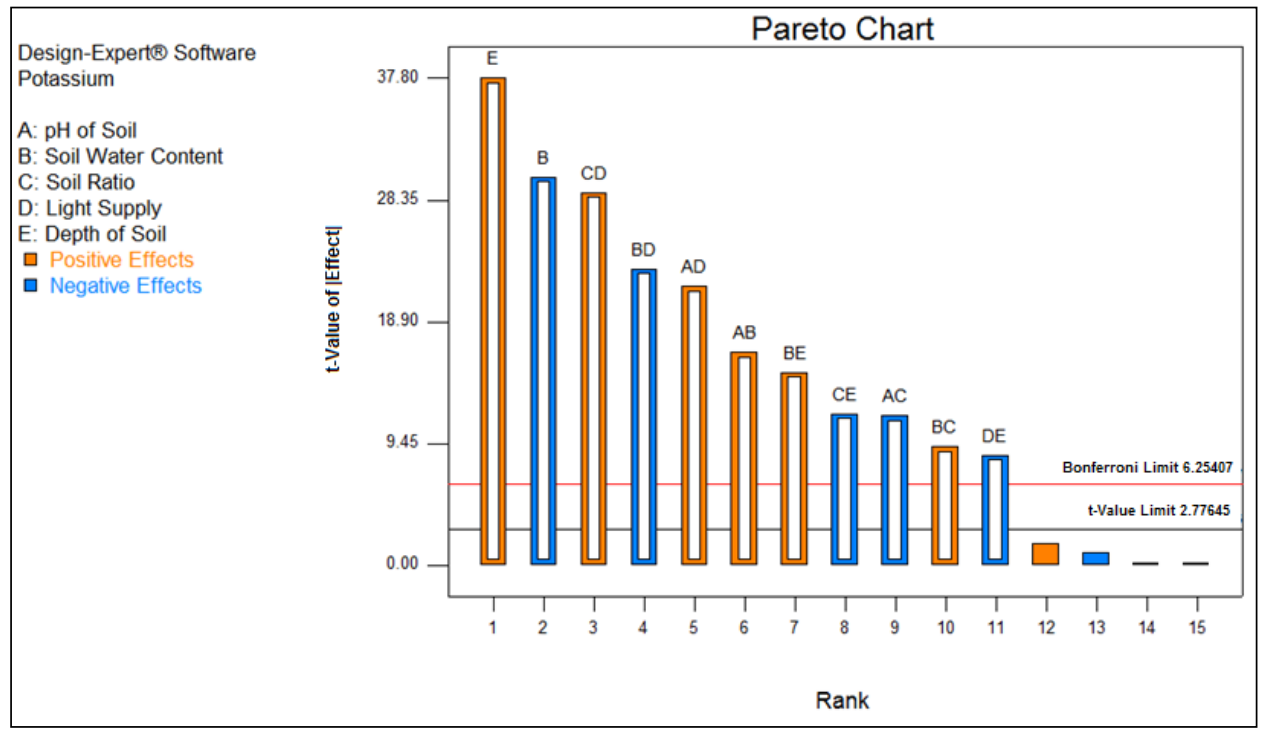

Fig. 3. Pareto chart for Potassium. 
Table 4. Analysis of variance table for K.

\begin{tabular}{|l|l|l|l|l|l|}
\hline $\begin{array}{l}\text { Source of } \\
\text { variation }\end{array}$ & $\begin{array}{l}\text { Sum of } \\
\text { squares }\end{array}$ & $\begin{array}{l}\text { Degree of } \\
\text { freedom }\end{array}$ & $\begin{array}{l}\text { Mean } \\
\text { square }\end{array}$ & F value & $\begin{array}{l}\text { p value } \\
\text { Prob>F }\end{array}$ \\
\hline Model & 48.84 & 11 & 4.44 & 463.30 & $<0.0001$ \\
\hline B, Water content & 8.70 & 1 & 8.70 & 908.10 & $<0.0001$ \\
\hline E, Depth of soil & 13.69 & 1 & 13.69 & 1428.55 & $<0.0001$ \\
\hline AB & 2.61 & 1 & 2.61 & 272.73 & $<0.0001$ \\
\hline AC & 1.28 & 1 & 1.28 & 134.03 & 0.0003 \\
\hline AD & 4.48 & 1 & 4.48 & 467.51 & $<0.0001$ \\
\hline BC & 0.81 & 1 & 0.81 & 84.52 & 0.0008 \\
\hline BD & 5.06 & 1 & 5.06 & 528.27 & $<0.0001$ \\
\hline BE & 2.15 & 1 & 2.15 & 224.47 & 0.0001 \\
\hline CD & 8.03 & 1 & 8.03 & 837.70 & $<0.0001$ \\
\hline CE & 1.32 & 1 & 1.32 & 138.00 & 0.0003 \\
\hline DE & 0.69 & 1 & 0.69 & 72.46 & 0.0010 \\
\hline Residual & 0.038 & 4 & $9.583 \mathrm{E}-0.03$ & & \\
\hline Correlation Total & 48.88 & 15 & & & \\
$\mathrm{R}^{2}$ & 0.9992 & & & & \\
Adj. R $^{2}$ & 0.9971 & & & & \\
\hline
\end{tabular}

\subsection{Best condition for flooded soil recovery}

The best condition selected by design expert is summarized in Table 5 . The $\mathrm{N}, \mathrm{P}$ and $\mathrm{K}$ are at their maximum concentration in a soil condition suggested by Design-Expert ${ }^{\circledR}$ software (Ver 7.1.6).

Table 6. Best soil condition for AMF to propagate as suggested by Design-Expert $\AA$ software (Ver 7.1.6).

\begin{tabular}{|c|c|c|c|c|}
\hline pH of soil & Water Content & SA:FS & Light Supply & Depth of Soil \\
\hline 4 & 28 & $1: 5$ & Present & $5 \mathrm{~cm}$ \\
\hline
\end{tabular}

\section{Conclusions}

This work demonstrates the feasibility of using experimental design tools to screen significant influential factors affecting the propagation of AMF in plant roots, which in turn increase the fertility of the soil itself. The best condition of the soil for AMF in taking up nutrient at their maximum rate was identified and the result can be further used to conduct an optimization work.

\section{References}

1. T.T. Kozlowski, BioScience, 34, 162 (1984)

2. P. Gosling, A. Hodge, G. Goodlass, G.D. Bending, Agr. Ecosyst. Environ., 113, 7 (2006)

3. D.S. Hayman, B. Mosse, New Phytol., 70, 19 (1971)

4. R.G. Linderman, E.A. Davis, HortTechnology, 14, 196 (2004)

5. P.M. Vitousek, R.W. Howarth, Biogeochemistry, 13, 87 (1991)

6. M. Govindaraju, P.E. Pfeffer, H. Jin, J. Abubaker, D.D. Douds, J.W. Allen, H. Buking, P.J. Lammers, Y. Shachar-Hill, Nature, 435, 819 (2005)

7. D.J. Read, Experientia, 47, 376 (1991)

8. D. Tilman, Ecol. Monogr., 57, 189 (1987) 
9. A. Hodge, D. Robinson, B.S. Griffiths, A.H. Fitter, Plant Cell Environ., 22, 811 (1999)

10. A. Shukla, S. Lahudkar, G. Durairaj, S.R. Bhaumik, Biochemistry, 51(2), 706 (2012)

11. B. Benito, R. Haro, A. Amtmann, T.A. Cuin, I. Dreyer, J. Plant. Physiol., 171, 723 (2014)

12. E. Adams, R. Shin, J. Integr. Plant Biol., 56 (3), 231 (2014) 